This is an Accepted Manuscript of a book chapter published by Routledge in Professor Michael Furmston (ed.), The Future of the Law of Contract on $8^{\text {th }}$ May 2020, available online: https://www.routledge.com/The-Future-of-the-Law-of-Contract-1stEdition/Furmston/p/book/9780367174033.

\title{
The Validity of Choice of Court Agreements in International Commercial Contracts under the Hague Choice of Court Convention and the Brussels la Regulation
}

\section{Mukarrum Ahmed*}

ORCID: 0000-0002-5451-9348

\begin{abstract}
This chapter will examine the validity of choice of court agreements in international commercial contracts under the Hague Choice of Court Convention and the EU's Brussels la Regulation. It will be argued that the significant lessons learnt from the jurisprudence on choice of court agreements under the Brussels la Regulation and its predecessor instruments should not be ignored. Unlike the CJEU's early and restrictive jurisprudence on the writing requirement, Article 3(c) of the Hague Convention should be broadly interpreted. The independent concept of consent distinct from the substantive validity of a choice of court agreement developed under Article 25 of the Brussels la Regulation should also be applied in the context of the Hague Convention. This autonomous and wide concept of consent will reduce the need to rely on the choice of law rule governing the substantive validity of choice of court agreements, which refers to the law of the chosen forum including its private international law rules. It will be observed that the unilateral national choice of law rules of the Member States and Contracting States may act as an impediment to the sound operation of the choice of law rule by creating uncertainty and risking decisional harmony.
\end{abstract}

\section{Keywords}

Private International Law, Conflict of Laws, International Commercial Litigation, Choice of Court Agreement, Jurisdiction, Applicable Law, Formal Validity, Consent, Substantive Validity, Capacity, Hague Choice of Court Convention, Brussels la Regulation, Rome I Regulation, Hague Choice of Law Principles.

\section{Introduction}

1. This chapter will examine the validity of choice of court agreements in international commercial contracts under the Brussels la Regulation ${ }^{1}$ and the Hague Convention on Choice of Court Agreements ('Hague Convention'). ${ }^{2}$ The central concern of this book is how the law of contract will develop in the years ahead. In this context, choice of court agreements give rise to issues of validity and capacity that require the application of the contract law of a

\footnotetext{
* Lecturer in Business Law at Lancaster University and a barrister of Lincoln's Inn. The author wishes to thank Professor Michael Furmston for his comments on a draft version of this chapter. Email: m.ahmed25@lancaster.ac.uk

${ }^{1}$ Council Regulation (EU) 1215/2012 of the European Parliament and of the Council of 12 December 2012 on jurisdiction and the recognition and enforcement of judgments in civil and commercial matters (recast) [2012] OJ L351/1 ('Brussels la Regulation'). See, generally, A Briggs, Private International Law in English Courts (OUP 2014); A Dickinson and E Lein (eds.), The Brussels I Regulation Recast (OUP 2015); R Fentiman, International Commercial Litigation ( $2^{\text {nd }}$ Edition, OUP 2015); TC Hartley, Civil Jurisdiction and Judgments in Europe (OUP 2017); M Ahmed, The Nature and Enforcement of Choice of Court Agreements (Hart Publishing 2017).

${ }^{2}$ Concluded at the 20th Session of the Hague Conference on Private International Law, The Hague, 30 June 2005. See, generally, Permanent Bureau of the Conference, Convention of 30 June 2005 on Choice of Court Agreements: Text and Explanatory Report by Trevor Hartley and Masato Dogauchi (HCCH Publications 2013) http://www.hcch.net/upload/expl37final.pdf accessed 22 May 2019; RA Brand and PM Herrup, The 2005 Hague Convention on Choice of Court Agreements (CUP 2008); TC Hartley, Choice of Court Agreements under the European and International Instruments (OUP 2013); Ahmed, Nature and Enforcement of Choice of Court Agreements (n 1).
} 
This is an Accepted Manuscript of a book chapter published by Routledge in Professor Michael Furmston (ed.), The Future of the Law of Contract on $8^{\text {th }}$ May 2020, available online: https://www.routledge.com/The-Future-of-the-Law-of-Contract-1stEdition/Furmston/p/book/9780367174033.

state. In the future, the scope and substance of the choice of law rule governing the substantive validity and/or capacity to enter into a choice of court agreement will be tested before the courts. A wide and independent notion of consent may emerge globally together with a simplified criterion for determining the formal validity of a choice of court agreement. Ultimately, in more doubtful penumbral cases, the advantages of an autonomous approach under the relevant instrument itself may have to be balanced against applying the choice of law rule which refers a matter to the contract law of a state.

2. The Brussels la Regulation is the European Union ('EU') regime governing jurisdiction and the recognition and enforcement of judgments in civil and commercial matters that applies from 10 January 2015 to legal proceedings instituted and to judgments rendered on or after that date. $^{3}$ The Hague Convention is an emerging international commercial litigation regime, which enforces exclusive choice of court agreements at both the jurisdictional and recognition and enforcement stages. On 1 October 2015, the Hague Convention entered into force in 28 Contracting States, including Mexico and all the Member States of the EU, except Denmark. ${ }^{4}$ Singapore ratified the Hague Convention on 2 June 2016 and the Convention applies between Singapore and the other Contracting States from 1 October 2016. ${ }^{5}$ The Convention has recently entered into force in Montenegro and Denmark on 1 August 2018 and 1 September 2018 respectively. ${ }^{6}$ Post-Brexit, it is likely that the Hague Convention will become a far more significant instrument because it will regulate the enforcement of exclusive choice of court agreements in the future civil judicial relationship between the UK and the EU. ${ }^{7}$

3. It will be argued that the significant lessons learnt from the jurisprudence on choice of court agreements under the EU's Brussels la Regulation and its predecessor instruments should not be ignored. Hence, the case law on the Brussels la Regulation will serve as a guide when navigating the provisions on the validity of choice of court agreements under the Hague Convention.

4. The chapter will commence by introducing the concept, scope and key provisions of the emergent Hague Convention. This will be followed by an overview of the juridical nature and anatomy of choice of court agreements, which will help contextualise our discussion of the validity of choice of court agreements. An assessment of the formal validity of choice of court agreements will reveal that contrary to the CJEU's early and restrictive jurisprudence on the writing requirement for choice of court agreements, the prevailing academic view does not support a strict interpretation of the formal requirements in Article 3(c) of the

\footnotetext{
${ }^{3}$ Article 81 of the Brussels la Regulation.

${ }^{4}$ On 4 December 2014, the Council adopted the decision to approve the Hague Convention on behalf of the European Union (2014/887/EU, [2014] OJ L353/5) after the European Parliament gave its consent to the approval of the Hague Convention by legislative resolution of 25 November 2014 ([2016] OJ C289/78). The Civil Jurisdiction and Judgments (Hague Convention on Choice of Court Agreements 2005) Regulations 2015, SI 2015/1644, have brought the Hague Convention into force in the UK.

${ }^{5}$ See A Chong and M Yip, 'Singapore as a centre for international commercial litigation: party autonomy to the fore' (2019) 15 Journal of Private International Law 97. In Ermgassen v Sixcap Financials [2018] SGHCR 8, the Singapore High Court became the first court to recognise and enforce a judgment under the Hague Convention.

${ }^{6}$ See the Hague Conference on Private International law website for the status table in relation to the Convention, https://www.hcch.net/en/instruments/conventions/status-table/?cid=98 accessed on 22 May 2019.

7 See M Ahmed, 'BREXIT and English Jurisdiction Agreements: The Post-Referendum Legal Landscape' (2016) 27 European Business Law Review 989, 994-997; G Rühl, 'Judicial Cooperation in Civil and Commercial Matters After Brexit: Which Way Forward?' (2018) 67 International and Comparative Law Quarterly 99, 127.
} 
This is an Accepted Manuscript of a book chapter published by Routledge in Professor Michael Furmston (ed.), The Future of the Law of Contract on $8^{\text {th }}$ May 2020, available online: https://www.routledge.com/The-Future-of-the-Law-of-Contract-1st-

Edition/Furmston/p/book/9780367174033.

Hague Convention. Moreover, it will be observed that Article 25(1)(a) of Brussels la is capable of subsuming the other formal requirements in Articles 25(1)(b)-(c) and Article 3(c) of the Hague Convention correctly jettisons these other formal requirements. An independent concept of consent distinct from the substantive validity of a choice of court agreement has developed under Article 25 of the Brussels la Regulation. It will be argued that a wide and independent notion of consent should also be applied in the context of the Hague Convention. This approach will ensure consistency and coherence of the Hague Convention with the Brussels I regime's existing jurisprudence. Significantly, it will reduce the need to rely on the choice of law rule governing the substantive validity of choice of court agreements, which refers to the law of the chosen forum including its private international law rules. The reference to the private international law rules of the chosen forum indicates that renvoi is permitted even though the EU choice of law Regulations on contractual and non-contractual obligations expressly forbid renvoi. It will be observed that the unilateral national private international law rules of the Member States and Contracting States will act as an impediment to the sound operation of the choice of law rule as the harmonised Rome I Regulation is inapplicable. ${ }^{8}$ Therefore, the choice of law rule on substantive validity may increase the litigation risk in multi-state transactions. ${ }^{9}$ The application of the Rome I Regulation will be the optimal solution for the choice of law rule governing substantive validity of choice of court agreements in the Brussels la Regulation and the Hague Convention. The choice of law rule on substantive validity should only be relied upon where there is a defect of consent (fraud, misrepresentation, duress or mistake), lack of authority or lack of capacity. Moreover, the need to rely on the choice of law rule governing substantive validity is alleviated because the technique of severability insulates the choice of court agreement by ensuring that only a specific attack on the validity of a choice of court clause will be assailable.

\section{Concept, Scope and Key Provisions of the Hague Convention}

5. This section explains the concept and general scope of the Hague Convention, prior to presenting an outline of its key provisions.

\section{Concept}

6. The Hague Convention is designed to create a mandatory international legal regime for the enforcement of exclusive choice of court agreements in commercial transactions and the recognition and enforcement of judgments resulting from proceedings based on such agreements. The Hague Convention operates in parallel with the very successful $1958 \mathrm{New}$ York Convention on the Recognition and Enforcement of Foreign Arbitral Awards. ${ }^{10}$ The

\footnotetext{
${ }^{8}$ Regulation (EC) No 593/2008 of the European Parliament and of the Council of 17 June 2008 on the law applicable to contractual obligations (Rome I) OJ L/2008/177/6 ('Rome I Regulation'). Post-Brexit, the UK government intends to retain the Rome I Regulation unilaterally by incorporating it into domestic law. See Rühl (n 7) 123-124.

${ }^{9}$ See Fentiman (n 1) Chapter 1, for a definition of 'litigation risk' in multi-state transactions.

${ }^{10}$ United Nations Convention on the Recognition and Enforcement of Foreign Arbitral Awards, 10 June, 1958, 330 UNTS 4739 ('New York Convention'). Cf R Garnett, 'The Hague Choice of Court Convention: Magnum Opus or Much Ado about Nothing?' (2009) 5 Journal of Private International Law 161, 171-73, doubts whether the Hague Convention is a true litigation counterpart of the New York Convention. This may be attributed to the presence of a wider range of excluded subject matter under Article 2 compared to international arbitration,
} 
This is an Accepted Manuscript of a book chapter published by Routledge in Professor Michael Furmston (ed.), The Future of the Law of Contract on $8^{\text {th }}$ May 2020, available online: https://www.routledge.com/The-Future-of-the-Law-of-Contract-1st-

Edition/Furmston/p/book/9780367174033.

choice of court agreement provisions in the Brussels la Regulation have been aligned with the Hague Convention in order to ensure better coordination and to secure the consistent enforcement of choice of court agreements both within the EU and globally. ${ }^{11}$ The rules coordinating conflicts between the private international law regimes of the Hague Convention and the Brussels la Regulation form part of an increasingly multi layered, multilateral and multi-speed regional and international legal order. According to the Hague Convention, the Convention will take precedence over the Brussels la Regulation if there is an actual incompatibility between the two instruments but excluding the situations where the parties reside exclusively within EU Member States and where recognition or enforcement of a judgment by an EU court is being sought within the EU. ${ }^{12}$

Scope

7. The Hague Convention applies to exclusive choice of court agreements in international cases in civil and commercial matters. ${ }^{13}$ Consumer and employment contracts are excluded from the scope of the Hague Convention. ${ }^{14}$ Together with further exclusions under Article 2(2), this leads to the result that the Hague Convention primarily applies in 'business to business' commercial cases. The Hague Convention only applies in international cases. The definition of what is an international case differs between jurisdictional issues (Chapter II) and recognition and enforcement issues (Chapter III). For the Hague Convention's jurisdictional rules to apply, a case is international unless the parties are resident in the same Contracting State and the relationship of the parties and all other elements relevant to the dispute, regardless of the location of the chosen court, are connected only with that State. ${ }^{15}$ For the purposes of obtaining the recognition and enforcement of a judgment in a Contracting State, it is sufficient that the judgment presented is foreign. ${ }^{16}$

\section{Key Provisions}

8. The basic principles of the Hague Convention can be outlined in a few sentences. ${ }^{17}$ The chosen court in an exclusive choice of court agreement shall have jurisdiction to decide a dispute which falls within its purview, unless the agreement is null and void under the law of that state. ${ }^{18}$ Any court other than the chosen court shall suspend or dismiss proceedings to which an exclusive choice of court agreement applies. ${ }^{19} \mathrm{~A}$ judgment given by a chosen court shall be recognized and enforced in other Contracting States and recognition and

the potentially wider defences to enforcement of agreements (particularly the 'manifest injustice' ground) and the scope for Contracting States to remove certain areas from the Convention under Article 21. Moreover, international arbitration offers advantages to parties relating to the process itself including neutrality, judicial support and arbitral institutions of the seat of arbitration, procedural flexibility, privacy and confidentiality.

${ }^{11}$ B Hess, T Pfeiffer and P Schlosser, 'Report on the Application of Regulation Brussels I in the Member States' (Study JLS/C4/2005/03, September 2007) ('Heidelberg Report') [338]-[344], [390], 95-7, 112.

12 Article 26(6) of the Hague Convention; Hartley and Dogauchi (n 2) [267]; Hartley, Choice of Court Agreements (n 2) Chapter 6, 121-26.

${ }^{13}$ Article 1(1) of the Hague Convention; see Brand and Herrup (n 2) Chapter 4.

${ }^{14}$ Article 2(1) of the Hague Convention.

${ }^{15}$ Article $1(2)$ of the Hague Convention.

${ }^{16}$ Article 1(3) of the Hague Convention.

${ }^{17}$ Hartley, Choice of Court Agreements (n 2) Chapter 1, 21-2; Brand and Herrup (n 2) Chapter 2, 11-4; Hartley and Dogauchi (n 2) [1].

${ }^{18}$ Article 5 of the Hague Convention.

${ }^{19}$ Article 6 of the Hague Convention. 
This is an Accepted Manuscript of a book chapter published by Routledge in Professor Michael Furmston (ed.), The Future of the Law of Contract on $8^{\text {th }}$ May 2020, available online: https://www.routledge.com/The-Future-of-the-Law-of-Contract-1stEdition/Furmston/p/book/9780367174033.

enforcement may be refused only on the grounds specified in the Hague Convention. ${ }^{20}$ Article 22 provides an optional fourth basic rule allowing each Contracting State the opportunity to declare that, on the basis of reciprocity, its courts will recognize and enforce judgments given by courts of other Contracting States designated in a non-exclusive choice of court agreement. ${ }^{21}$ Article 22 is based on the assumption that some Contracting States may opt for enhanced judicial cooperation beyond the minimum mandatory framework of the Hague Convention.

9. A court designated by a choice of court agreement has no power under the Hague Convention to stay its proceedings on forum non conveniens grounds or to stay its proceedings on the basis of the lis alibi pendens doctrine. ${ }^{22}$ This should be interpreted as the conferral of a right on the parties to invoke the jurisdiction of the chosen court. However, in relation to non-international cases, Article 19 of the Hague Convention allows a Contracting State to declare that its courts will not exercise jurisdiction when, except for the location of the chosen court, there is no connection between that State and the parties or the dispute. Thus, if a declaration pursuant to Article 19 has been made, the possibility of declining jurisdiction effectively trumps the rule in Article 5(2). ${ }^{23}$

\section{The Nature and Anatomy of Choice of Court Agreements}

10. The substantive and procedural aspects of a choice of court agreement warrant the classification of a 'hybrid' contract. ${ }^{24}$ The dual nature of the choice of court agreement is manifested both as a private law contract and via the clause's procedural (jurisdictional) effects. The applicable law of a choice of court agreement reflects this dual classification.

11. Issues of interpretation, formal and substantive validity and enforceability represent the anatomy of a choice of court agreement. There are two distinct aspects of interpretation: whether the clause is 'exclusive' or 'non-exclusive' and whether the scope of the clause applies to the claims raised by the claimant in the proceedings. ${ }^{25}$ Formal validity is regulated by the instrument itself (i.e. Hague Convention or the Brussels la Regulation), which provides uniform and autonomous rules, whereas substantive validity is subject to the law of the chosen forum including its private international law rules. The enforcement of choice of court agreements is governed by the autonomous rules of the instruments. ${ }^{26}$ Under the

\footnotetext{
${ }^{20}$ Article 8 of the Hague Convention.

${ }^{21}$ Article 22 of the Hague Convention.

${ }^{22}$ Article 5(2) of the Hague Convention; see Brand and Herrup (n 2) Chapter 5, 82-4; RA Brand and SR Jablonski, Forum Non Conveniens: History, Global Practice, and Future Under the Hague Convention on Choice of Court Agreements (OUP 2007) Chapter 9, 208.

${ }^{23}$ Brand and Herrup (n 2) Chapter 5, 84; P Beaumont, 'Hague Choice of Court Agreements Convention 2005: Background, Negotiations, Analysis and Current Status' (2009) 5 Journal of Private International Law 125, 149. No party to the Convention has made the Article 19 declaration so far.

${ }^{24}$ Ahmed, Nature and Enforcement of Choice of Court Agreements (n 1) 37; See also, Hartley, Choice of Court Agreements (n 2) 4- 6, 129-30; B Hess, 'The Draft Hague Convention on Choice of Court Agreements, External Competencies of the European Union and Recent Case Law of the European Court of Justice' in A Nuyts and N Watté (eds.), International Civil Litigation in Europe and Relations with Third States (Bruylant 2005) 263, 271; Hartley, Civil Jurisdiction and Judgments in Europe (n 1) 227.

${ }^{25}$ Article 25(1) of Brussels la provides an autonomous presumption that the choice of court agreement shall be exclusive unless the parties have agreed otherwise. Cf Article 3(b) of the Hague Convention. In relation to the scope of the clause, the CJEU has confirmed that questions of interpretation are a matter for Member State courts and the applicable national law: See infra $\mathrm{n} 66$.

${ }^{26}$ Article 31(2) of the Brussels la Regulation; Articles 5 and 6 of the Hague Convention.
} 
This is an Accepted Manuscript of a book chapter published by Routledge in Professor Michael Furmston (ed.), The Future of the Law of Contract on $8^{\text {th }}$ May 2020, available online: https://www.routledge.com/The-Future-of-the-Law-of-Contract-1stEdition/Furmston/p/book/9780367174033.

English common law regime and to the extent permitted by the autonomous system of the instruments, ${ }^{27}$ anti-suit injunctions, actions for damages and anti-enforcement injunctions may enforce the breach of a choice of court agreement. ${ }^{28} \mathrm{~A}$ stay of proceedings may be granted where a foreign choice of court agreement has been breached by contrary proceedings in the forum..$^{29}$ The law of the forum governs remedies for breach of choice of court agreements in the English common law regime. ${ }^{30}$

12. This map of related issues has provided context to our discussion of the validity of choice of court agreements under the Hague Convention and the Brussels la Regulation.

\section{Formal Validity and Consent in Choice of Court Agreements}

13. Both the Brussels la Regulation and the Hague Convention prescribe formal requirements that must be satisfied if the choice of court agreement is to be considered valid. Consent is also a necessary requirement for the validity of a choice of court clause. ${ }^{31}$ Although formal validity and consent are independent concepts, the two requirements are connected because the very purpose of the formal requirements is to guarantee the existence of consent. ${ }^{32}$ If the formal requirements are met, this may be taken to constitute the existence of consent. Alternatively, if the requirements of form are not satisfied, the court may find that there was an absence of consent.

14. The CJEU has referred to the close relationship between formal validity and consent in a number of its decisions. The court has made the validity of a choice of court agreement subject to an 'agreement' between the parties. ${ }^{33}$ The Brussels la Regulation imposes upon the Member State court the duty of examining whether the clause conferring jurisdiction was in fact the subject of consensus between the parties, which must be clearly and precisely demonstrated. ${ }^{34}$ The court has also stated that the very purpose of the formal

\footnotetext{
${ }^{27}$ In Case C-159/02 Turner v. Grovit [2005] ECR I-3565 and Case C-185/07 Allianz SpA v. West Tankers Inc [2009] 1 Lloyd's Rep 413, the CJEU has held that the legal technique used by the English courts to prevent a party from commencing or continuing proceedings in breach of a jurisdiction or arbitration agreement, the anti-suit injunction, could not be granted in circumstances in which the foreign proceedings are before the courts of another EU Member State and are within the scope of the Brussels I Regulation. See M Ahmed, 'The enforcement of settlement and jurisdiction agreements and parallel proceedings in the European Union: The Alexandros T litigation in the English courts' (2015) 11 Journal of Private International Law 406, 412-415.

${ }^{28} \mathrm{M}$ Ahmed and P Beaumont, 'Exclusive choice of court agreements: some issues on the Hague Convention on choice of court agreements and its relationship with the Brussels I recast especially anti-suit injunctions, concurrent proceedings and the implications of BREXIT' (2017) 13 Journal of Private International Law 386, 394-408.

${ }^{29}$ Ahmed, Nature and Enforcement of Choice of Court Agreements (n 1) 2.

${ }^{30} \mathrm{Cf}$ A Briggs, 'The Unrestrained Reach of an Anti-Suit Injunction: A Pause for Thought' [1997] Lloyd's Maritime and Commercial Law Quarterly 90; C Sim, 'Choice of Law and Anti-Suit Injunctions: Relocating Comity' (2013) 62 International and Comparative Law Quarterly 703.

${ }^{31}$ Case C-322/14 Jaouad El Majdoub v CarsOnTheWeb.Deutschland GmbH ECLI:EU:C:2015:334, [26]; Case C-543/10 Refcomp SpA v Axa Corporate Solutions Assurance SA and Others ECLI:EU:C:2013:62, [26].

32 Jaouad El Majdoub (n 31) [30]; Refcomp (n 31) [28].

${ }^{33}$ Case C-387/98 Coreck Maritime GmbH v Handelsveem BV and Others ECLI:EU:C:2000:606, [13]; Case C-24/76 Estasis Salotti di Colzani Aimo e Gianmario Colzani s.n.c. $v$ Rüwa Polstereimaschinen GmbH ECLI:EU:C:1976:177, [7]; Case C-25/76 Galeries Segoura SPRL $v$ Société Rahim Bonakdarian ECLI:EU:C:1976:178, [6]; Case C-106/95 Mainschiffahrts-Genossenschaft eG (MSG) v Les Gravières Rhénanes SARL ECLI:EU:C:1997:70, [15].

${ }^{34}$ Ibid.
} 
This is an Accepted Manuscript of a book chapter published by Routledge in Professor Michael Furmston (ed.), The Future of the Law of Contract on $8^{\text {th }}$ May 2020, available online: https://www.routledge.com/The-Future-of-the-Law-of-Contract-1stEdition/Furmston/p/book/9780367174033.

requirements imposed by Article $17^{35}$ (now Article 25 of Brussels la) is to ensure that consensus between the parties is in fact established. ${ }^{36}$

15. Article 25(1) of the Brussels la Regulation allows the parties to agree upon conferring jurisdiction on a Member State court subject to the agreement satisfying the formal validity requirements. The formal validity requirements for choice of court agreements under the Brussels la Regulation have evolved over time into their current state. ${ }^{37}$ The choice of court agreement must be either: ${ }^{38}$

1. in writing or evidenced in writing; ${ }^{39}$

2. in a form which accords with practices which the parties have established between themselves; or

3. in international trade or commerce, in a form which accords with a usage of which the parties are or ought to have been aware and which in such trade or commerce is widely known to, and regularly observed by, parties to contracts of the type involved in the particular trade or commerce concerned.

16. A party seeking to rely on a choice of court agreement must have a 'good arguable case' that Article 25(1) of Brussels la Regulation's formal requirements are satisfied. ${ }^{40}$ The formal requirements cannot be overridden or amended by the national law of Member States and Member State law cannot prescribe additional requirements of form. ${ }^{41}$

17. In the CJEU's nascent jurisprudence on the Brussels I regime, the requirement that the choice of court agreement be in writing or evidenced in writing was construed strictly. In addition to the designation of a particular Member State court in writing, consent was also required to be in writing. In Colzani, the CJEU required that the contract be signed by both parties and should contain an express reference to the general conditions which contained the choice of court agreement in order to ensure that the other party had really consented and had an opportunity to check the clause by exercising reasonable care. ${ }^{42}$

18. In Segoura, the parties entered into an oral contract for the sale of goods where the choice of court agreement was not discussed. ${ }^{43}$ However, when the goods were delivered, the seller handed the buyer a document which expressly stated on the front that the sale and delivery were subject to the conditions on the reverse. The choice of court agreement was printed on the reverse amongst the conditions. The CJEU ruled that: ${ }^{44}$

\footnotetext{
${ }^{35}$ Article 17 of the 1968 Brussels Convention on jurisdiction and the enforcement of judgments in civil and commercial matters OJ L 299, 31.12.1972, p 32.

${ }^{36}$ Case 313/85 Iveco Fiat v Van Hool ECLI:EU:C:1986:423, [5].

${ }^{37}$ The present version of the text was finalised when Spain and Portugal acceded to the Brussels Convention in 1989. This version of the text was inherited by the Brussels I Regulation (2001) and the Brussels la Regulation (2012). See Hartley, Civil Jurisdiction and Judgments in Europe (n 1) Chapter 13.

${ }^{38} \mathrm{Cf}$ For the formal requirements of an arbitration agreement see, Section 5 of the English Arbitration Act 1996.

39 As per Article 25(2), any communication by electronic means which provides a durable record of the agreement is treated as 'writing'. A 'click wrap' agreement is 'in writing' for the purposes of Article 25 because the text of the terms and conditions containing the choice of court agreement can be printed and saved before the conclusion of the contract: Jaouad El Majdoub (n 31); See A Dickinson, "Click Wrapping" Choice of Court Agreements in the Brussels I Regime' [2016] Lloyd's Maritime and Commercial Law Quarterly 15.

${ }^{40}$ Bols Distilleries (t/a as Bols Royal Distilleries) v Superior Yacht Services Ltd [2006] UKPC 45 (Lord Rodger).

${ }^{41}$ Case 150/80 Elefanten Schuh GmbH v Pierre Jacqmain ECLI:EU:C:1981:148, [26].

${ }^{42}$ Colzani (n 33) [9].

${ }^{43}$ Segoura (n 33).

${ }^{44}$ Ibid [8].
} 
This is an Accepted Manuscript of a book chapter published by Routledge in Professor Michael Furmston (ed.), The Future of the Law of Contract on $8^{\text {th }}$ May 2020, available online: https://www.routledge.com/The-Future-of-the-Law-of-Contract-1stEdition/Furmston/p/book/9780367174033.

Even if, in an orally concluded contract, the purchaser agrees to abide by the vendor's general conditions, he is not for that reason to be deemed to have agreed to any clause conferring jurisdiction which might appear in those general conditions.

19. The court said that the position would be different if the oral agreement was part of a continuing trading relationship between the parties and the dealings between the parties as a whole were governed by the general conditions of the party giving the confirmation, and these conditions contained a choice of court agreement. Under these circumstances, it would be contrary to good faith for the recipient of the confirmation to deny that he had agreed to the choice of court agreement. ${ }^{45}$

20. Under Article 25(1)(a) of the Brussels la Regulation, it is also possible to have an oral agreement 'evidenced in writing'. In Berghoefer, the contract contained a choice of court agreement nominating a French court. ${ }^{46}$ However, there was a subsequent oral agreement that the chosen court would be in Germany. A written document setting out what had been agreed was received by the other party but there was no response. The CJEU held that there was a choice of court agreement evidenced in writing. ${ }^{47}$ The court also held that it was immaterial that the choice of court agreement was in favour of the party providing the written confirmation. ${ }^{48}$

21. Prima facie, it might be difficult to reconcile the decisions in Segoura with Berghoefer. In Segoura, the parties had agreed that the contract would be subject to the vendor's general conditions. The general conditions contained the choice of court agreement but there was no express oral agreement in relation to the choice of court clause. The CJEU adjudicated that this was insufficient. On the other hand, in Berghoefer there was an express oral agreement about the choice of court agreement. Once this oral agreement was evidenced in writing, the requirements of the Brussels I regime were satisfied.

22. It has been argued that the scope of application of the formal requirements in Article 25(1) of the Brussels la Regulation overlap. ${ }^{49}$ It appears that Article 25(1)(c) covers Article 25(1)(b) as it is applicable where the parties have previously had business relations. As compared to Article 25(1)(a), the other two formal requirements allow oral agreements on jurisdiction. However, oral agreements are less likely to be encountered in international commerce where parties usually provide objective evidence of their contract through writing. Article 25(1)(a) of the Brussels la Regulation is capable of subsuming the other formal requirements, because the decision in Berghoefer demonstrates that an oral agreement on choice of court can later be evidenced in writing..$^{50}$ The reluctance of the delegations to adopt the other two formal requirements in Article 3(c) of the Hague Convention seems justified. ${ }^{51}$

23. Under the Hague Convention, consent is an essential constituent of a choice of court agreement. The autonomous notion of consent applies independently of the law of any

\footnotetext{
45 Ibid [11].

${ }^{46}$ Case 221/84 F. Berghoefer GmbH \& Co. KG v ASA SA ECLI:EU:C:1985:337.

47 Ibid [14].

48 Ibid.

${ }^{49}$ P Beaumont and B Yüksel, 'The Validity of Choice of Court Agreements under the Brussels I Regulation and the Hague Choice of Court Agreements Convention' in K Boele-Woelki, T Einhorn, D Girsberger and S Symeonides (eds.), Convergence and Divergence in Private International Law: Liber Amicorum Kurt Siehr (Eleven International Publishing 2010) 563, 571; PR Beaumont and PE McEleavy, Anton's Private International Law (3 ${ }^{\text {rd }}$ Edition, W Green 2011) 248-249.

50 lbid.

${ }^{51}$ See Hartley, Civil Jurisdiction and Judgments in Europe (n 1) 264.
} 
This is an Accepted Manuscript of a book chapter published by Routledge in Professor Michael Furmston (ed.), The Future of the Law of Contract on $8^{\text {th }}$ May 2020, available online: https://www.routledge.com/The-Future-of-the-Law-of-Contract-1st-

Edition/Furmston/p/book/9780367174033.

Contracting State and is governed by the Convention itself. However, the legal effect of fraud, mistake, duress and other defects of consent is determined by the law of the Contracting State designated in the choice of court agreement including its private international law rules. This follows from the choice of law rule that a choice of court agreement is invalid if it is null and void under the law of the State of the chosen court. ${ }^{52}$ The choice of law rule governing material validity cannot encroach on the rules explicitly laid down in the Convention. As a result, the requirement of the Convention that consent must exist cannot be determined by the law of the State of the chosen court. ${ }^{53} \mathrm{~A}$ distinction may therefore be drawn between the factual existence and the substantive validity of a choice of court agreement.

24. Article 3(c) of the Hague Convention lays down the requirements of form for a choice of court agreement. These formal requirements cannot be overridden or amended and no additional formal requirements can be imposed by the law of a Contracting State..$^{54}$

Article 3(c) of the Hague Convention states:

[A]n exclusive choice of court agreement must be concluded or documented ${ }^{55}-$

(i) in writing; or

(ii) by any other means of communication which renders information accessible so as to be usable for subsequent reference. ${ }^{56}$

25. This is different from the equivalent provision in the Brussels la Regulation and needs further analysis. The Hartley and Dogauchi Report explains that where the agreement is in writing, its formal validity is not dependent on it being signed. ${ }^{57}$ However, the lack of signature might render it more difficult to prove the existence of the agreement. ${ }^{58}$ The Hartley and Dogauchi Report also states that if the agreement is oral and one party puts it into writing, it does not matter if he was the one who benefitted from it because the chosen court was in his country. ${ }^{59}$

26. The prevailing academic authority does not support a strict interpretation of the formal requirements in Article 3(c) of the Hague Convention. ${ }^{60}$ Therefore, it would be wrong for courts in the EU Member States and the other Contracting States of the Hague Convention to adhere to the strict interpretation originally given by the CJEU to Article 25(1)(a) of the Brussels la Regulation in decisions such as Colzani and Segoura. ${ }^{61}$ A choice of court agreement on the reverse of the contract should suffice, if the other party was aware that it

\footnotetext{
52 Articles 5(1), 6(a) and 9(a) of the Hague Convention.

53 Hartley and Dogauchi (n 2) [94]-[96].

54 Ibid [110].

55 ibid [113]: The phrase 'evidenced in writing' in Article 25(1)(a) of the Brussels la Regulation was replaced with 'documented in writing'.

${ }^{56}$ This provision has the same effect as Article 25(2) of the Brussels la Regulation. Both provisions are inspired by Article 6(1) of the UNCITRAL Model Law on Electronic Commerce 1996.

${ }^{57}$ Hartley and Dogauchi (n 2) [112].

58 Ibid.

59 Ibid [114].

60 See Hartley, Civil Jurisdiction and Judgments in Europe (n 1) 265, notes that a more liberal approach is justified in the Hague Convention because only commercial transactions are covered and controversial matters such as carriage of goods by sea are excluded. See also, Brand and Herrup (n 2) 46; Beaumont and McEleavy (n 49) 261.

${ }^{61}$ See supra $\mathrm{n} 33$.
} 
This is an Accepted Manuscript of a book chapter published by Routledge in Professor Michael Furmston (ed.), The Future of the Law of Contract on $8^{\text {th }}$ May 2020, available online: https://www.routledge.com/The-Future-of-the-Law-of-Contract-1stEdition/Furmston/p/book/9780367174033.

should look at the back of the contract. In similar vein, a choice of court agreement in a separate document given to the other party should suffice if it was aware that it should read it. An express oral agreement prior to a written confirmation should not necessarily be required. An objective test of reasonableness should guide the application of the formal validity provision in the Hague Convention.

\section{Substantive Validity of Choice of Court Agreements}

27. Article 23 of the Brussels I Regulation did not contain an express provision on the substantive validity of a choice of court agreement. ${ }^{62}$ The law of some Member States referred substantive validity of a choice of court agreement to the law of the forum whereas other Member States referred it to the applicable law of the substantive contract. ${ }^{63}$ However, the Brussels la Regulation applies the law of the forum prorogatum (chosen forum) including its choice of law rules to the issue of the substantive validity of a choice of court agreement. ${ }^{64}$ Under Article 25(1) the elected court shall have jurisdiction 'unless the agreement is null and void as to its substantive validity under the law of that Member State'. ${ }^{65}$ The CJEU has confirmed that questions of interpretation are a matter for Member State courts and the applicable national law. ${ }^{66}$

${ }^{62}$ Council Regulation (EC) 44/2001 on jurisdiction and the recognition and enforcement of judgments in civil and commercial matters (Brussels I) [2001] OJ L12/1. See Beaumont and McEleavy (n 49) Chapter 8, 249-55; ZS Tang, Jurisdiction and Arbitration Agreements in International Commercial Law (Routledge 2014) Chapter 2, $22-25$. Cf Briggs (n 1) $251-52$, terms the reference to the law of the chosen court including its private international law rules to assess matters of substantive validity as 'retrograde'; A Briggs, Agreements on Jurisdiction and Choice of Law (OUP 2008) 257, advances the view that 'Article 23 does not require, and is not necessarily satisfied by, a contractually-binding agreement on jurisdiction'; A Dickinson, 'Surveying the Proposed Brussels I bis Regulation - Solid Foundations but Renovation Needed' (2010) 12 Yearbook of Private International Law 247, 301, contends that a solution to the issue is unnecessary and that the CJEU has already achieved a high level of legal certainty by affirming that the consent of the parties is to be determined solely by reference to the requirements of Article 23 of the Brussels I Regulation. Moreover, Dickinson argues that the new provision should not be used by Member State courts to permit a challenge to the validity of choice of court agreements on grounds which the CJEU has interpreted autonomously, ie CJEU jurisprudence should not be reversed; L Merrett, 'Article 23 of the Brussels I Regulation: A Comprehensive Code for Jurisdiction Agreements?' (2009) 58 International and Comparative Law Quarterly 545, argues that the requirements of Article 23 are both necessary and sufficient conditions for the material validity of jurisdiction agreements in Brussels I Regulation cases and if any other tool is needed to deal with cases where the jurisdiction agreement itself is directly impeached, a Community notion of good faith is the appropriate way to deal with such cases.

${ }^{63}$ See Heidelberg Report ( $\mathrm{n} 11$ ) [326], 92.

${ }^{64}$ Article 25(1) and Recital 20 of the Brussels la Regulation. For an early proposal to the same effect under the Brussels Convention, see AG Slynn in Case 150/80 Elefanten Schuh GmbH $v$ Pierre Jacqmain ECLI:EU:C:1981:112, 1697-1698; In Case C-222/15 Höszig Kft. $v$ Alstom Power Thermal Services ECLI:EU:C:2016:224, [47], AG Szpunar examined the scope of the lex fori prorogatum rule and suggested that the new formulation does not attempt to reverse the CJEU's case law on the autonomous determination of consent. For a similar argument, see U Magnus and P Mankowski (eds.), Brussels Ibis Regulation (Cologne, Verlag Dr Otto Schmidt, 2016) 628; Dickinson and Lein (n 1) 298.

${ }^{65}$ The phrase 'null and void' might be interpreted to exclude 'voidable' acts. A more accurate and specific provision would not limit the choice of law rule on substantive validity to just 'void' choice of court agreements: See U Magnus, 'Choice of Court Agreements in the Review Proposal for the Brussels I Regulation' in E Lein (ed.), The Brussels I Review Proposal Uncovered (BIICL 2012) 83, 93. Cf Section 9(4) of the English Arbitration Act 1996 and Article II(3) of the New York Convention.

${ }^{66}$ Case C-352/13 Cartel Damage Claims (CDC) Hydrogen Peroxide SA v Evonik Degussa GmbH and Others ECLI:EU:C:2015:335, [67]; Case C-214/89 Powell Duffryn plc v Wolfgang Petereit [1992] ECR I-01745 [36]-[37]; 
This is an Accepted Manuscript of a book chapter published by Routledge in Professor Michael Furmston (ed.), The Future of the Law of Contract on $8^{\text {th }}$ May 2020, available online: https://www.routledge.com/The-Future-of-the-Law-of-Contract-1stEdition/Furmston/p/book/9780367174033.

28. There is a contrary indication in the Hartley and Dogauchi Report of the Hague Convention that most 'consent' questions are governed by the choice of law rules established to determine substantive validity and capacity. ${ }^{67}$ However, Beaumont has warned us about the dangers in the argument that issues of consent are governed by either 'the law of the forum - including its choice of law rules' ${ }^{\prime 68}$ or even the law of the chosen forum including its choice of law rules. ${ }^{69}$ It should be noted that in both the Brussels la Regulation and the Hague Convention, the general principle of consent applies independently of the law of any Member State or Contracting State and follows autonomously from the instrument itself. ${ }^{70}$ The Brussels la Regulation and the Hague Convention provide a complete system of rules to determine whether there is a choice of court agreement. ${ }^{71}$

29. The policy basis animating the selection of the law of the chosen court including its choice of law rules is to render the Brussels la Regulation compatible with the Hague Convention. The wording of the rules for substantive validity for choice of court agreements in both the instruments is almost identical. ${ }^{72}$ This has facilitated the approval of the Hague Convention by the $\mathrm{EU}$ and ensures the consistent treatment of issues of substantive validity of choice of court agreements under both the Brussels la Regulation and under the Hague Convention.

30. The application of 'substantive validity' should be limited to the contractual validity of the choice of court clause and should not extend to its jurisdictional or procedural effects. It is submitted that subjecting the procedural aspects of the choice of court agreement to the choice of law rule for substantive validity will undermine the fundamental structure of both the Hague Convention and the Brussels la Regulation. The national law of a Member State or Contracting State should apply to defects of consent that impair or negate the contractual validity of a choice of court agreement. Procedural issues such as whether a valid choice of court agreement may be incorporated into a contract with a weaker party (consumer or employee) is concerned with its jurisdictional effect. A characterisation issue of contemporary practical relevance relates to whether the perceived incompatibility of asymmetric choice of court agreements with the Brussels la Regulation is subject to the choice of law rule regulating substantive validity or the autonomous procedural effect of a choice of court agreement. ${ }^{73}$ The Hague Convention only applies to exclusive choice of court agreements as opposed to asymmetric choice of court agreements. ${ }^{74}$

Case C-269/95 Francesco Benincasa v Dentalkit Srl [1997] ECR I-03767 [31]; Roche Products v Provimi [2003] EWHC 961 (Comm), [81] (Aikens J).

${ }^{67}$ Hartley and Dogauchi (n 2) [94]-[96].

${ }^{68}$ Brand and Herrup (n 2) 79. Cf RA Brand, 'The Evolving Private International Law/Private Law Overlap in the European Union' in P Mankowski and W Wurmnest (ed.), Festschrift für Ulrich Magnus (Dr Otto Schmidt 2014) 371.

${ }^{69}$ Beaumont (n 23) 139.

${ }^{70}$ Hartley (n 2) 133; Beaumont (n 23) 139.

${ }^{71}$ For the Brussels la Regulation, see Refcomp (n 31) [21]; Case C-222/15 Höszig Kft. v Alstom Power Thermal Services ECLI:EU:C:2016:525 [29].

72 Article 25(1) of the Brussels la Regulation; Article 5(1) of the Hague Convention.

${ }^{73} \mathrm{M}$ Ahmed, 'The Legal Regulation and Enforcement of Asymmetric Jurisdiction Agreements in the European Union' (2017) 28 European Business Law Review 403, 412-413; L Merrett, 'The Future Enforcement of Asymmetric Jurisdiction Agreements' (2018) 67 International and Comparative Law Quarterly 37, 51; Fentiman (n 1) 82; Hartley, Civil Jurisdiction and Judgments in Europe (n 1) 265; J Strnad, 'Determining the Existence of Consent for Choice-of-Court Agreements under the Brussels I-bis Regulation' (2014) 14 The European Legal Forum 113, 117-118.

${ }^{74}$ Article 3(a) of the Hague Convention; Minutes No. 3 of the Twentieth Session, Commission II, [2]-[11]; Hartley and Dogauchi (n 2) [106]; See Ahmed, Nature and Enforcement of Choice of Court Agreements (n 1) 231. Cf Merrett (n 73) 58. 
This is an Accepted Manuscript of a book chapter published by Routledge in Professor Michael Furmston (ed.), The Future of the Law of Contract on $8^{\text {th }}$ May 2020, available online: https://www.routledge.com/The-Future-of-the-Law-of-Contract-1stEdition/Furmston/p/book/9780367174033.

31. According to Recital 20 of the Brussels la Regulation the reference to the nominated court's law includes both its substantive law and its choice of law rules. Therefore it is clear that the inclusion of renvoi within Article 25 is intended and the question whether a choice of court agreement is materially valid is therefore to be ascertained under the substantive law to which the choice of law rules of the Member State of the chosen court refer. ${ }^{75}$

32. Some commentators have questioned whether renvoi should be applied in determining the substantive validity of a choice of court agreement. ${ }^{76}$ They argue that contractual relations governed by party autonomy should exclude renvoi from the application of choice of law rules. ${ }^{77}$ The exclusion of renvoi from the choice of law regimes of the Rome $\mathrm{I}^{78}$ and Rome $\mathrm{II}^{79}$ Regulations is evidence that certainty and predictability may be compromised by the application of renvoi. Moreover, the unilateral national private international law rules of the Member States may act as an impediment to the sound operation of the choice of law rule as the harmonised Rome I Regulation is inapplicable. It is argued that the choice of law rule on substantive validity may increase litigation risk in multi-state transactions and should only be relied upon where there is a defect of consent (fraud, misrepresentation, duress or mistake), lack of authority or lack of capacity. ${ }^{80}$ It should not extend to issues of contractual enforceability that are extrinsic to the consent or capacity of the parties, such as illegality or public policy. ${ }^{81}$

33. However, in some cases it may be unreasonable to apply the substantive law of the forum prorogatum to the issue of capacity. ${ }^{82}$ The forum chosen by the parties is often due to its neutrality and efficient dispute resolution and the chosen forum may have a tenuous connection with the actual dispute. In such cases it may be preferable to apply the choice of law rules of the chosen forum to determine the capacity of a party to enter into a choice of court agreement. The application of renvoi in these cases will lead to the application of a law closely connected to the dispute. In similar vein, where the parties have made a choice of law agreement that differs from the substantive law usually applied before the forum prorogatum, renvoi to the chosen law should be applied in deference to the principle of party autonomy. ${ }^{83}$ In the absence of an express choice of law agreement, the court will have to determine the law applicable to the substantive validity of the choice of court agreement. ${ }^{84}$ In this regard, a forum where a choice of court agreement is a strong indication of implied choice of law of the chosen court will be at an advantage compared to

\footnotetext{
75 For a discussion of renvoi, see L Collins and others (eds.), Dicey, Morris and Collins on the Conflict of Laws (Sweet \& Maxwell 2012) Chapter 4; JJ Fawcett and JM Carruthers, Cheshire, North and Fawcett: Private International Law (OUP 2008) Chapter 5; Beaumont and McEleavy (n 49) Chapter 4, 100 - 09.

${ }^{76}$ B Hess, 'The Brussels I Regulation: Recent Case Law of the Court of Justice and the Commission's Proposed Recast' (2012) 49 Common Market Law Review 1075, 1107; P Hay, 'Notes on the European Union's Brussels-I "Recast" Regulation' (2013) 13 The European Legal Forum 1, 3; K Takahashi, 'Damages for Breach of a Choice of Court Agreement: Remaining Issues' [2009] Yearbook of Private International Law 73, 85; Briggs (n 1) 252.

77 PE Nygh, Autonomy in International Contracts (OUP 1999) $83-84$.

${ }^{78}$ Article 20 of the Rome I Regulation.

${ }^{79}$ Article 24 of Regulation 864/2007 EC on the law applicable to non-contractual obligations [2007] OJ L199/40 ('Rome II Regulation').

${ }^{80}$ Dickinson and Lein (n 1) 297; Magnus and Mankowski (n 64) 630; See also, Merrett (n 73) 51.

81 Ibid.

82 T Ratkovic' and Rotar D Zgrabljic', 'Choice-of-Court Agreements under the Brussels I Regulation (Recast)' (2013) 9 Journal of Private International Law 245, 258.

${ }^{83}$ Beaumont and McEleavy ( $\mathrm{n}$ 49) Chapter 8, 254 - 55; See generally, M Ahmed, 'The Nature and Enforcement of Choice of Law Agreements' (2018) 14 Journal of Private International Law 500.

${ }^{84}$ Beaumont and Yüksel (n 49) 576.
} 
This is an Accepted Manuscript of a book chapter published by Routledge in Professor Michael Furmston (ed.), The Future of the Law of Contract on $8^{\text {th }}$ May 2020, available online: https://www.routledge.com/The-Future-of-the-Law-of-Contract-1stEdition/Furmston/p/book/9780367174033.

a forum where a choice of court agreement is just one of the factors that could determine whether a choice of law has been clearly demonstrated. ${ }^{85}$

34. On the other hand, in the case of other defects of consent, it is not clear how renvoi can help in determining the substantive validity of a choice of court agreement. The substantive law of the chosen court may provide an appropriate legal regime to govern such issues, making a reference to the choice of law rules of the chosen court unnecessary. The factors pointing away from the law of the forum prorogatum in issues of capacity may not exert the same pull in relation to the other defects of consent. Indeed, the law of a neutral forum may negative any advantage available under a law closely connected to the dispute such as the applicable law of the underlying contract. The doctrines of severability ${ }^{86}$ and Dépeçage ${ }^{87}$ allow the choice of court agreement to be governed by a law separate from the law governing the underlying contract. In fact, a separate law governing the choice of court agreement may ensure the continued validity of such agreements where the entire contract is impeached.

35. Difficult issues of proof of foreign law arise with the application of the doctrine of renvoi. Unlike civil law legal systems, foreign law is a question of fact in the English common law. ${ }^{88}$ Therefore, the party relying on foreign law is required to plead and prove the content of foreign law. ${ }^{89}$ When applying the doctrine of renvoi, evidence of the foreign rules on renvoi and foreign choice of law rules have to be pleaded and proved in the English common law courts..$^{90}$ In civil law legal systems, evidence of the foreign choice of law rules will suffice for the application of the doctrine of renvoi. ${ }^{91}$ However, the inherent advantage of the English common law's pragmatic approach to foreign law is that the parties can choose not to rely on the foreign law by not pleading it. ${ }^{92}$ English law as the law of the forum is applied instead. ${ }^{93}$ Secondly, the English courts usually apply English law as a default where the content of the foreign law is not proved. ${ }^{94}$ An analogy may be drawn between the parties not relying on the foreign law and a delayed choice of English law to govern the dispute. ${ }^{95} \mathrm{~A}$ flexible approach to proof of foreign law in English courts may help the litigants ignore the doctrine of renvoi altogether by not pleading and proving the applicable law.

36. The Rome I Regulation does not apply to choice of court agreements. ${ }^{96}$ National choice of law rules will govern the issue of the substantive validity of a choice of court agreement. ${ }^{97}$ The lack of harmonisation of national choice of law rules may lead to uncertainty in the

\footnotetext{
85 Recital 12 of the Rome I Regulation. See Briggs (n 1) 541.

${ }^{86}$ Article 25(5) of the Brussels la Regulation; Article 3(d) of the Hague Convention.

87 See 'Dépeçage' ('Splitting the applicable law'); see Article 3(1) of the Rome I Regulation and the Rome Convention; Collins ( 75 ) Chapter 32, 1789 - 92; Beaumont and McEleavy ( 49 ) Chapter 10, $454-55$.

${ }^{88}$ A Briggs, The Conflict of Laws ( $3^{\text {rd }}$ Edition, OUP 2013) Chapter 1, $7-13$.

89 Ibid.

${ }^{90}$ Hartley, Choice of Court Agreements (n 2) Chapter 7, 165- 67: reference to the 'foreign court' or 'double renvoi' or 'total renvoi' theory adopted by England and many other common law countries.

91 ibid: reference to the 'single renvoi' theory adopted by France and Germany.

92 Briggs (n 88).

93 Ibid.

94 Ibid.

95 See Article 3(2) of the Rome I Regulation and the Rome Convention; Collins (n 75) Chapter 32, 1805 - 06 ; Beaumont and McEleavy (n 49) Chapter 10, 455 - 56.

${ }^{96}$ Article 1(2)(e) of the Rome I Regulation; Article 1(2)(d) of the Rome Convention; see M Giuliano and P Lagarde, 'Report on the Convention on the Law Applicable to Contractual Obligations ' [1980] OJ C282/1, 11 12; Collins (n 75) Chapter 32, 1788; Beaumont and McEleavy (n 49) Chapter 10, $434-39$.

${ }^{97}$ Heidelberg Report (n 11) [326] - [327], 92.
} 
This is an Accepted Manuscript of a book chapter published by Routledge in Professor Michael Furmston (ed.), The Future of the Law of Contract on $8^{\text {th }}$ May 2020, available online: https://www.routledge.com/The-Future-of-the-Law-of-Contract-1stEdition/Furmston/p/book/9780367174033.

determination of the applicable law of the choice of court agreement. For instance, in English law the 'proper law' of the choice of court agreement, which is quite often the applicable law of the underlying contract, applies. ${ }^{98}$ The proper law is the term which was used at common law to signify the law by which the validity of the contract is tested, and is used in this context to acknowledge that the identification of the law which governs a choice of court agreement is a matter for the common law rules of the conflict of laws.

37. Although the Rome I Regulation excludes choice of court agreements from its scope, it is argued that the analogical application of the choice of law regime by the law of the forum would result in an optimal solution where the same law governs the validity of the choice of court agreement and the underlying contract. ${ }^{99}$ In practice, this would secure a uniform standard for the applicable law rules of choice of court agreements. However, the lingering conceptual problem with this solution is that Article 20 of the Rome I Regulation excludes renvoi and Article 25 of the Brussels la Regulation has created an applicable law rule which permits renvoi. ${ }^{100}$ The Hague Principles of Choice of Law in International Commercial Contracts do not address the law governing choice of court agreements. ${ }^{101}$ However, the widespread adoption and application of the Hague Principles to choice of court agreements will ensure that the autonomy of the parties as to the applicable law of the choice of court agreement is respected globally irrespective of the forum seised.

38. The Hartley and Dogauchi Report elucidates that 'null and void' applies only to substantive grounds of invalidity. ${ }^{102}$ The choice of law rule governing substantive validity should only apply to defects of consent (fraud, misrepresentation, duress or mistake). The choice of law rule cannot override or amend the form requirements in Article 3(c) and leaves no room for the national law of a Contracting State to apply to issues of form. This interpretation of the ambit of the choice of law rule regulating substantive validity is in alignment with the position under the Brussels la Regulation.

39. The Hartley and Dogachi Report further states that the law of the chosen court includes the choice of law rules of that Contracting State. Therefore, renvoi is permitted. It is submitted that that unilateral national choice of law rules that permits renvoi may increase the litigation risk in multi-state transactions and should only be relied upon where there is a defect of consent. ${ }^{103}$ The choice of law rule should not extend to issues of contractual

${ }^{98}$ Collins (n 75) Chapter 12, 603 - 04; D Joseph, Jurisdiction and Arbitration Agreements and their Enforcement (Sweet \& Maxwell 2010) 182; Briggs ( $\mathrm{n}$ 88) 231; see Sulamerica CIA Nacional de Seguros SA and others (Sulamérica) v Enesa Engenharia SA and others (Enesa) [2012] EWCA Civ 638, [2012] 1 All ER (Comm) 795.

99 See Dickinson and Lein (n 1) 297; Magnus and Mankowski (n 64) 629; MH Ballesteros, 'The Regime of Party Autonomy in the Brussels I Recast: The Solutions Adopted for Agreements on Jurisdiction' (2014) 10 Journal of Private International Law 291, 299 - 300; See also, SP Camilleri, 'Article 23: Formal Validity, Material Validity or Both?' (2011) 7 Journal of Private International Law 297, 313-318. Cf Beaumont and Yüksel (n 49) 576, argue that in the absence of an express or implied choice of law, the court's analysis should not extend to the objective applicable law rules and the court should apply the internal law of the chosen court as renvoi has to be applied consistently with party autonomy.

100 Ahmed, Nature and Enforcement of Choice of Court Agreements (n 1) 219.

${ }^{101}$ Article 1(3)(b) and [1.26] of the Hague Choice of Law Principles and Commentary in Permanent Bureau of the Conference, The Hague Principles on Choice of Law in International Commercial Contracts (Approved on 19 March 2015) https://assets.hcch.net/docs/5da3ed47-f54d-4c43-aaef-5eafc7c1f2a1.pdf accessed on 22 May 2019.

102 Hartley and Dogauchi (n 2) [126].

${ }^{103}$ C Kessedjian, 'Commentaire de la refonte du règlement $n^{\circ} 44 / 2001^{\prime}$ (2011) 47 Revue trimestrielle de droit européen 117, $126-27$, has foreseen that the introduction of a choice of law element into the substantive validity of jurisdiction agreements under Article 25 of Brussels la will have the knock-on effect of increasing the number of disputes concerning the validity of such agreements. 
This is an Accepted Manuscript of a book chapter published by Routledge in Professor Michael Furmston (ed.), The Future of the Law of Contract on $8^{\text {th }}$ May 2020, available online: https://www.routledge.com/The-Future-of-the-Law-of-Contract-1st-

Edition/Furmston/p/book/9780367174033.

enforceability that are extrinsic to the consent or capacity of the parties, such as illegality or public policy. ${ }^{104}$ The application of the Rome I Regulation to the choice of law rule governing substantive validity in the courts of Member States (who are also Contracting States) will result in greater certainty by ensuring decisional harmony regardless of forum.

40. The Hague Convention contains a special choice of law rule on capacity to enter into a choice of court agreement. A choice of court agreement is invalid if one of the contracting parties lacked capacity to conclude it by either the law of the chosen court or the law of the forum. As opposed to the Brussels la Regulation, under the Hague Convention, capacity is both an element of essential validity and a separate concept. ${ }^{105}$ If the chosen court is seised, the choice of law rule for capacity will not engage as the law of the chosen court and the law of the forum are synonymous. However, if a non-chosen court is seised, the issue of capacity of either party to conclude the choice of court agreement will be referred to both the law of the chosen court and the law of the forum. It should be noted that incapacity under the law of the forum includes the choice of law rules of the forum. Therefore, renvoi is permitted and the law of the forum may refer the issue of capacity to its internal law, the law of the chosen court or the law of a third state based on the party's domicile or other personal connecting factor.

\section{Severability of Choice of Court Agreements}

41. Article 25(5) of the Brussels la Regulation enshrines the technique of severability by providing that a choice of court agreement which forms part of a wider contract must be treated as a separate agreement. ${ }^{106}$ Article 3(d) of the Hague Convention contains an almost identical provision on severability. ${ }^{107}$ Severability of choice of court agreements was established by the CJEU jurisprudence prior to its explicit provision in the Brussels la Regulation. ${ }^{108}$ In Benincasa $v$ Dentalkit, the CJEU found that a void contract does not render the choice of court agreement void as well. ${ }^{109}$

42. The technique of severability serves to insulate the choice of court agreement from the invalidity of the underlying contract. A challenge to the validity of the underlying contract will not on its own impugn the validity of the choice of court agreement. However, a specific attack on the validity of the choice of court agreement may impeach it. The doctrines of severability and Dépeçage allow the choice of court agreement to be governed by a law

\footnotetext{
104 Dickinson and Lein (n 1) 297; Magnus and Mankowski (n 64) 630; See also, Merrett (n 73) 51.

105 Hartley and Dogauchi (n 2) [150] and [184].

106 The legal basis of the technique of severability may be questioned because as a matter of logic a choice of court agreement should be invalid where the entire contract in which it is situated has been invalidated. However, concerns of a pragmatic nature prevent the choice of court agreement from succumbing to the same fate as the rest of the contractual provisions. Cf infra $\mathrm{n}$ 110. The pragmatic legal basis of severability may be compared with the concept of the putative applicable law (or 'putative proper law') of the contract, which governs the material validity of the contract (Article 10 of the Rome I Regulation). The putative applicable law is the law that would govern the contract in the event that it was valid in the first place. A logical circularity is involved as the concept of the putative applicable law assumes the very validity of the contract, which it is supposed to ascertain.

${ }^{107}$ Cf Section 7 of the English Arbitration Act 1996. The technique of severability was confirmed in the English common law by Fiona Trust and Holding Corp v Privalov [2007] UKHL 40. See Briggs (n 62) Chapter 3.

108 Powell Duffryn plc v Wolfgang Petereit (n 66); Francesco Benincasa v Dentalkit Srl (n 66); Case C-159/97 Trasporti Castelletti Spedizioni Internazionali SpA v Hugo Trumpy SpA [1999] ECR I-01597.

${ }^{109}$ Francesco Benincasa v Dentalkit SrI (n 66) [24] - [29]. See also Trasporti Castelletti Spedizioni Internazionali SpA v Hugo Trumpy SpA (n 108) [34], [49], [51].
} 
This is an Accepted Manuscript of a book chapter published by Routledge in Professor Michael Furmston (ed.), The Future of the Law of Contract on $8^{\text {th }}$ May 2020, available online: https://www.routledge.com/The-Future-of-the-Law-of-Contract-1st-

Edition/Furmston/p/book/9780367174033.

separate from the law governing the underlying contract. ${ }^{110}$ In fact a separate law governing the choice of court agreement may ensure the continued validity of such agreements where the entire contract is impugned. ${ }^{111}$ The principles of party autonomy and legal certainty provide the justification and legal basis for the technique of severability.

43. The practical application of the technique of severability will mean that issues of the substantive validity of a choice of court agreement will only arise where the validity of a choice of court agreement is specifically challenged. Severability therefore acts as a first line of defence by seeking to prevent any question of the substantive validity of the choice of court agreement from arising in the first place.

\section{Conclusions}

44. It has been observed that the dispensation with the additional formal requirements of a choice of court agreement in the Hague Convention is an application of Occam's razor. What emerges is a simple yet justifiable criterion that the choice of court agreement has to be 'in writing or documented in writing'. The CJEU's nascent jurisprudence on choice of court agreements under the Brussels I regime in Colzani and Segoura narrowly construed the 'in writing or evidenced in writing' formal requirement. It has been argued that Member State courts and the courts of other Contracting States should disregard this strict interpretation when applying Article 3(c) of the Hague Convention. As a result, a choice of court agreement on the reverse of the contract should suffice, if the other party was aware that it should look at the back of the contract. In similar vein, a choice of court agreement in a separate document given to the other party should suffice if it was aware that it should read it. An express oral agreement prior to a written confirmation should not necessarily be required. An objective test of reasonableness should guide the application of the formal validity provision in the Hague Convention.

45. An independent concept of consent has developed under Article 25 of the Brussels la Regulation and the corresponding provisions of its predecessor instruments. This notion of consent is distinct from substantive validity and is closely linked to the formal requirements of a choice of court agreement. As a matter of procedure, consent is autonomously governed by the relevant instrument. It has been argued that a wide and independent notion of consent should also be applied in the context of the Hague Convention. This approach will ensure consistency and coherence of the Hague Convention with the Brussels I regime's existing jurisprudence.

46. Significantly, it will reduce the need to rely on the choice of law rule governing the substantive validity of choice of court agreements, which refers to the law of the chosen forum including its private international law rules. The reference to the private international law rules of the chosen forum indicates that renvoi is permitted even though the EU choice

\footnotetext{
110 Cf A narrow conception of severability for arbitration agreements finds support in recent English and commonwealth decisions: The implied choice of law for the arbitration agreement is likely to be the same as the expressly chosen law of the underlying contract. See Sulamérica v. Enesa (n 98) [26]-[27] (Moore-Bick LJ with whom Hallett LJ agreed); $B C Y \vee B C Z$ [2016] SGHC 249, [49] (Steven Chong J) (Singapore High Court); National Thermal Power Corporation vs Singer Company And Ors (1993) AIR 998, [1992] SCR (3) 106 (TK Thommen J) (Supreme Court of India). See also, R Nazzini, 'The Law Applicable to the Arbitration Agreement' (2016) 65 International and Comparative Law Quarterly 681, 687-689.

${ }^{111}$ In Francesco Benincasa v Dentalkit Srl (n 66), the application of national substantive law to the validity of the choice of court agreement was dismissed in order to protect the entire contract from being void under that law. The CJEU held that the choice of court agreement served a 'procedural purpose' and was governed by the autonomous provisions of the Brussels Convention.
} 
of law Regulations on contractual and non-contractual obligations expressly forbid renvoi. It has been noted that the unilateral national choice of law rules of the Member States may act as an impediment to the sound operation of the choice of law rule. The application of the Rome I Regulation will be the optimal solution for the choice of law rule governing substantive validity under the Brussels la Regulation and the Hague Convention. Globally, the widespread adoption and application of the Hague Choice of Law Principles to choice of court agreements will ensure that the autonomy of the parties as to the applicable law of the choice of court agreement is honoured regardless of the forum seised. Otherwise, the choice of law rule on substantive validity may increase the litigation risk in multi-state transactions by creating uncertainty and risking decisional harmony. It has been argued that the scope of the choice of law rule on substantive validity should be narrowly interpreted and only be relied upon where there is a defect of consent (fraud, misrepresentation, duress or mistake), lack of authority or lack of capacity. It should not extend to issues of contractual enforceability that are extrinsic to the consent or capacity of the parties, such as illegality or public policy. Moreover, the need to rely on the choice of law rule governing substantive validity is alleviated because the technique of severability insulates the choice of court agreement by ensuring that only a specific attack on the validity of a choice of court clause will be assailable.

47. In the future, the scope and substance of the choice of law rule governing the substantive validity and/or capacity to enter into a choice of court agreement will be tested before the courts. Ultimately, in more doubtful penumbral cases, the advantages of an autonomous approach under the relevant instrument itself may have to be balanced against applying the choice of law rule which refers a matter to the contract law of a state. 